\title{
7 \\ UN CASO DE BENCHMARKING ORGANIZACIONAL PARA LA CIENCIA Y TECNOLOGİA DE LOS AÑOS 1930/40 ${ }^{1}$
}

\author{
Arnoldo Oscar Delgado (*) \\ Laboratorio de Investigaciones \\ del Territorio y el Ambiente (LINTA)
}

\section{RESUMEN}

La inauguración del Laboratorio de Ensayo de Materiales del Ministerio de Obras Públicas de la Provincia de Buenos Aires (LEMOP), primero de su tipo en el país, fue precedida por la extensa travesía de su futuro Director a través de los Estados Unidos de Norteamérica a fin de estudiar las mejores prácticas de instituciones similares que pudieran aplicarse en la organización e instalaciones locales todavía en construcción. En sintonía con las actuales técnicas del benchmarking empresarial, la experiencia se repitió apenas dos años después antecediendo a su reconversión como Laboratorio de Ensayo de Materiales e Investigaciones Tecnológicas (LEMIT), esta vez con visitas a institutos de Brasil reconocidos por su buena interacción con el sector productivo. El presente trabajo reseña estas iniciativas absolutamente innovadoras para el medio argentino de su época, así como la adaptación de las enseñanzas derivadas para optimizar el cumplimiento de la misión y objetivos principales de la organización: la profesionalización de las actividades de investigación, la formación de recursos humanos de excelencia y la asistencia a la industria nacional.

\section{PALABRAS CLAVE:}

investigación científica y tecnológica, industria, políticas públicas, recursos económico-financieros, recursos humanos.

\footnotetext{
(•)E-mail: oscaradelgado@hotmail.com
}

\section{ABSTRACT}

The opening of the Materials Testing Laboratory of the Ministry of Public Works of Buenos Aires Province (LEMOP), first of its kind in Argentina, was preceded by the long journey of its future Director throughout the United States of North America in order to study the best practices of similar institutions to be applied in the local organization and facilities still in building process. According to current entrepreneurial benchmarking techniques, the experience was repeated two years later in anticipation of LEMOP reformulation as Materials Testing Laboratory and Technological Research (LEMIT), this time visiting Brazilian institutions well known because of their close interaction with productive sector. Present paper describes these initiatives absolutely innovative for the Argentinean environment, as well as the further adaptations of the learning achieved for better fulfill institutional mission and main objectives: turning research activity into a professional one, persuing excellence in human resources training and providing assistance to the national industry.

\section{KEY WORDS :}

scientific and technological research, industry, public policies, economic-financial resources, human resources.

RECEPCIŌN : $17 / 06 / 15$

ACEPTACIÓN FINAL: 21/12/15 